Hirata, S.R.; Queiroz, O.T.M.M. Percepção do visitante sobre a relação entre turismo e meio ambiente no município de Campos do Jordão (SP). Anais do VIII Congresso Nacional de Ecoturismo e do IV Encontro Interdisciplinar de Ecoturismo em Unidades de Conservação. Revista Brasileira de Ecoturismo, São Paulo, v.4, n.4, 2011, p. 555.

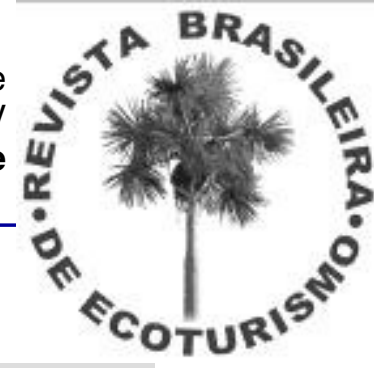

\title{
PERCEPÇÃO DO VISITANTE SOBRE A RELAÇÃO ENTRE TURISMO E MEIO AMBIENTE NO MUNICÍPIO DE CAMPOS DO JORDÃO (SP)
}

\author{
Sara Ruiz Hirata*, Odaléia Telles Marcondes Machado Queiroz* \\ *Escola Superior de Agricultura 'Luiz de Queiroz' - USP \\ E-mails: sarahirata@gmail.com, otmmquei@esalq.usp.br
}

Diante da emergência da temática ambiental e sua relevância e repercussão na sociedade, nota-se a importância de estudar a relação entre o homem e a natureza. Nesse sentido, observa-se que a atividade turística, geralmente, é construída por essa interação, sendo dependente dos recursos naturais dos núcleos receptores para sua existência e desenvolvimento. Apesar de ser visto como uma alternativa atraente em termos econômicos, o turismo é questionado em relação aos possíveis efeitos indesejáveis no que tange aos aspectos sociais e ambientais. Ciente disso, este artigo aborda o setor em Campos do Jordão, município do estado de São Paulo que recebe intenso fluxo turístico, principalmente nos meses de inverno devido as suas características de relevo e clima. Em uma análise preliminar, é apresentada uma visão do turismo em Campos do Jordão sob a ótica de 72 turistas entrevistados pelos alunos do curso de bacharelado em Gestão Ambiental da Escola Superior de Agricultura "Luiz de Queiroz", campus da Universidade de São Paulo, durante prática orientada no local. Contando com uma revisão bibliográfica sobre os assuntos abordados, o artigo objetivou, principalmente, discutir as atividades turísticas em Campos do Jordão considerando a percepção ambiental e motivação dos turistas, destacando a sua interação com o Parque Estadual de Campos do Jordão no período de 2007 a 2011, baseando em dados obtidos em prática orientada realizada por alunos do curso de Gestão Ambiental da ESALQ/USP. As informações obtidas viabilizaram uma análise prévia sobre o perfil do visitante e o segmento de turismo local. Sucintamente, constatou-se que os visitantes, na maioria, têm o ensino superior completo, se deslocam de veículo próprio, indicando que esses pertencem à uma classe social razoavelmente abastada, oriundos da capital, São Paulo. Pode-se dizer que há turistas de diferentes perfis freqüentando Campos do Jordão, muitos objetivam uma vivência relacionada aos aspectos urbanos concentrados na Vila do Capivari, ambiente sofisticado em clima semelhante ao europeu, elemento muito valorizado socialmente. Esta parcela vai raramente ao PECJ. Por outro lado, há os turistas que também são altamente motivados pela ocorrência de temperaturas mais baixas e raras no território paulista, mas sentem-se fortemente atraídos pelas belezas cênicas da região, ansiosos pelo contato com a natureza e são estes que visitam o Parque Estadual de Campos do Jordão, evidenciando-se, a priori, uma relação pouco complementar entre as áreas turística urbana e rural do município. Os resultados indicaram, entre outros fatores, que os impactos socioambientais, como um todo, são notados superficialmente, pela maioria dos visitantes, e aqueles efeitos que são percebidos relacionam-se, quase exclusivamente, à geração de lixo e esgoto. Os efeitos do turismo sobre o agravamento da desigualdade social, sobre os recursos hídricos e florestais são bem pouco observados.

Palavras-chave: Turismo; Campos do Jordão; Percepção. 